\title{
Analysis of Value-Added Tax Restitution on Exports at PT. Rama Global in 2019
}

\author{
Alian Natision ${ }^{1}$, Cindy Anggraini ${ }^{2}$, Novianita Rulandari ${ }^{3}$, Redjeki Agoestyowati ${ }^{4}$ \\ ${ }^{1234}$ Institut Ilmu Sosial dan Manajemen STIAMI, Jakarta, Indonesia \\ ${ }^{1}$ Correspondent: aliannatision07@gmail.com
}

\author{
Received : August 08, 2021 \\ Accepted : August 25, 2021 \\ Published : October 31, 2021
}

Citation: Natision, A., Anggraini, C., Rulandari, N., Agoestyowati, R.(2021 Analysis of ValueAdded Tax Restitution on Exports at PT. Rama Global in 2019. Ilomata International Journal of Tax \& Accounting 2(4),313-322. https://doi.org/10.52728/ijtc.v2i4.379

\begin{abstract}
PT Rama Global is a trading company that carries out preliminary restitution under certain conditions. The purpose of this paper is to find out how the preliminary restitution with certain requirements in the context of tax planning is carried out by PT. Rama Global, how are the obstacles faced in making tax refunds, and what efforts are being made to deal with these obstacles.

The method used is a qualitative method with data collection techniques, namely interviews, observation, documentation, and triangulation. Based on observations, PT Rama Global is an export company that input tax is greater than the output tax. PT Rama Global chose to restitute the tax with a preliminary restitution, but there will be some refunds that cannot be withdrawn, so PT Rama Global confirms the transaction with the counterparty.
\end{abstract}

Keywords: Value-Added Tax, Restitution, Export

\section{INTRODUCTION}

Taxes are things that are often encountered in everyday life, one of which is export taxes. Export tax is a tax that will be imposed by the government for an export activity. Export tax is also a tax on goods or services payable when an item leaves the exporting country or when the service is rendered to a foreign national. Export taxes consist of export duties, export benefits and exchange rate taxes. The export tax policy of each country varies depending on which tax system is adopted by that country. (Solleder, 2020; Zhang et al., 2021)

Export taxes are generally levied by countries producing raw materials. Differential exchange rates are often used to increase tax revenues from the export sector of raw materials, such as crude oil, palm oil, rubber, and various mining products. Export taxes are also influenced by international cartels which have determined several categories of export taxes. (Rehm et al., 2021; Tran \& Wende, 2021)

Export taxes are an effective protection measure for domestic industries. The governments of Norway and Sweden impose taxes on the export of forest products in order to protect the domestic milling, woodworking and paper-making industries. Meanwhile an export tax is imposed by the Government of India on untanned leather to encourage the tannery industry in India. However, in some countries, the export tax imposed is designed to protect the industry of the importing country and not the exporting country. (Federici et al., 2020) 
In Indonesia, where the export activities can be in the form of exporting Taxable Goods or BKP and Taxable Services or JKP. In general, the export tax is often imposed on export activities related to taxable services. Even so, there are still some categories of taxable goods that can also be subject to export tax. An entrepreneur who becomes a taxpayer, of course, has tax obligations including export taxes. (Rokhmawati, 2021)

The tax collection system that inspirits the Indonesian Taxation Law is a self-assessment system, where taxpayers are trusted to have an active role in fulfilling their tax obligations, namely calculating, depositing, and reporting taxes owed. Concerning the self-assessment system, the Taxation Law gives several rights to the Taxable Entrepreneur (PKP) in carrying out and fulfilling their tax obligations which can be broadly grouped into four main rights, namely: First, the right to receive NPWP (Taxpayer Registration Number); Second, the right to make compensation or restitution; Third, the right to object and appeal; and Fourth, the right to correct and extend the deadline for submitting a tax return (SPT). (Amir et al., 2013)

Taxpayers (WP) who are Taxable Entrepreneurs (PKP) who have insufficient payment of ValueAdded Tax (VAT) are required to pay off the unpaid tax, while Taxable Entrepreneurs (PKP) who have tax overpayments can compensate for the overpayment to the next tax period or apply for the excess of taxes or restitution payment. (Rahwani et al., 2019)

The proposal for restitution of Value Added Tax can be made during each tax period, but only the Taxable Entrepreneur can export the Tangible Taxable Goods, submit the Taxable Goods or Taxable Services to the VAT (Value Added Tax) Collector, submit Taxable Goods or Taxable Services that are not collected VAT (Value Added Tax), exports of Intangible Taxable Goods, exports of Taxable Services or are still in the non-production stage, other than Taxable Entrepreneurs can only make restitution at the end of the financial year. (Hajawiyah et al., 2021)

PT Rama Global is one of the companies that always apply for VAT restitution because their business activities are exports. PT Rama Global is a company that has a high level of competitiveness because it has an extensive business network in both local and international areas. PT Rama Global's high competitiveness can be seen from its export activities which have covered the international region. PT Rama Global's export activities are subject to VAT on Output Tax, thus causing VAT overpayments. (Harjo, 2019; Mardiasmo, 2016)

The excess payment of value-added tax that was experienced by PT Rama Global is submitted for a return request or called restitution. Restitution carried out by PT Rama Global aims to smooth business activities related to the cash flow of taxpayers. (Rahayu, 2010)

From the description above, the phenomenon that occurs is the number of tax restitution carried out in Indonesia, one of them is PT Rama Global, and therefor the author needs to conduct a research entitled Analysis of Value-Added Tax Restitution on Exports at PT. Rama Global Year 2019. In this research, the author limits the scope of the problem to only VAT refunds on export activities in the context of tax planning at PT Rama Global in 2019. (Asriati \& Sasmito, 2016)

Based on the subject matter above, the purpose of this research is to analyze the restitution of Value-Added Tax on exports; analyze what obstacles are faced in carrying out Value-Added Tax Restitution on exports, and analyze the efforts to deal with the constraints of VAT restitution on exports carried out by PT Rama Global in 2019.

Based on previous research entitled Anticipating Value-Added Tax Restitution for Export and Import Activities at PT YKK Zipco Indonesia, shows that PT. YKK Zipco Indonesia calculates VAT on export and import activities starting from data input, reporting until submission for restitution is correct and in accordance with the VAT Law no. 42 of 2009 (Rahmadani \& Munawaroh, 2017). The strategy in anticipating the occurrence of VAT restitution that was carried 
out starting in 2013 with several policy changes, so the strategic decisions done by the company in 2016 were to increase the efficiency and effectiveness of company. The tax planning that was carried out by PT. YKK ZIPCO Indonesia is very influential in anticipating VAT restitution, this can be seen in the company's compliance as taxpayers with government regulations, by completing every document required in the tax audit conducted by the Directorate General of Taxes (DGT). To anticipate the occurrence of VAT restitution, tax planning carried out by the company is to use a bonded zone facility, based on the Regulation of the Minister of Finance of the Republic of Indonesia Number 147/PMK.04/2011.

Furthermore, a research entitled Time Value of Money Analysis of Value-Added Tax Restitution Settlement Process (Case Study of PT XY Corporate Taxpayer). The results of the study concluded that PT XY's VAT refund occurred because of its main business activities were in the export sector with completion through a complicated and time-consuming inspection process step. The refund requested by PT XY for the long term makes the refund received related to the time value of money. Comparison of PT XY's restitution if the money is received more quickly, then it is a time deposit with an interest rate without risk. Bank Indonesia, has a higher value than the return on money that has been received in the long term. The refund process required is practical, easy and accurate, requiring good preparation and assessment by PT XY with a new policy on VAT refunds. (Ariawan et al., 2016)

Meanwhile, research entitled Restitution of VAT on Export Activities in the Context of Tax Planning (Case Study of PT. Y.I), concludes that VAT refunds carried out (P.T YI) in nominal and time terms have implications for cash flow. If the VAT refund application is successful with a small correction rate, the cash flow can run normally and vice versa. In the beginning, the tax planning efforts made to minimize the company's cash flow burden has not been optimal, therefore efforts were made to improve tax planning both internally and externally. (Samudra, $\underline{2008)}$

Research entitled Analysis of the Value-Added Tax Restitution (VAT) Restitution Process in Indonesia concluded that the VAT restitution process in Indonesia as regulated in the law and has not been carried out online causes complicated procedures related to VAT restitution, both internal or external DGT, the amount of workload borne by the tax authorities, and the length of the VAT restitution to the Taxpayer. The VAT restitution process in Indonesia is regulated by law is necessary to deregulate the regulation therefore that the VAT restitution process will be faster. In addition, VAT restitution should be made online to reduce the period and the procedure itself. (Octavia et al., 2015)

Following research entitled The Effect of Value-Added Tax Restitution on Value Added Tax Revenue at the Palembang Ilir Barat Pratama Tax Office, it had a conclusion that Value-Added Tax restitution did not affect Value-Added Tax Revenue at the Pratama Tax Service Office, Palembang Ilir Barat. This is because when submitting an application for restitution, not all applications for restitution are approved by the Pratama Tax Service Office, Palembang Ilir Barat. If there is a refund of the nominal amount of the overpaid tax, it does not affect the amount of existing Value-Added Tax Revenue. This is because the percentage of taxpayers who submit applications for restitution that are not approved is smaller than the percentage of taxpayers who submit applications for restitution that are approved. (Jusmani \& Qurniawan, 2016)

The latest research on tax refunds, through a research entitled Input Value-Added Tax Refund Policy for Taxable Enterprise Experiencing Production Failures or Policy of Value-Added Tax Refund for Taxable Entrepreneurs Experiencing Production Failures, concluded that there is a difference between the law, general concept and legal nature of VAT. On the other hand, the regulation was revised to prevent misuse of the VAT refund mechanism. Problems that may arise 
from this new regulation are problems related to regulatory consistency in the basic concept of VAT, and economic disincentives that can be experienced by Taxable Entrepreneurs from certain industries. Therefore, at a macro level, this policy can hamper investment growth in Indonesia. (Oktaria, 2011)

Restitution is an overpayment of Value-Added Tax that occurs because the amount of Input Tax paid is greater than the amount of Output Tax collected in a Tax Period. Government Regulation No. 3 of 2002 Article 1 point 5 Restitution is compensation given to the victim or the family by the doer or a third party, it can be in the form of returning property, payment of compensation for loss or suffering or reimbursement of costs for certain actions. Law on General Provisions of Taxation Article 17B Tax restitution is the right of the taxpayer (the Agency) if the value of the input tax is greater than the output tax. It is very unfair when generalizing all taxpayers (the Agency) that they commit tax evasion. What if the person applying for restitution is a taxpayer (Agency) who has good intention? With this stigma and image, there are doubts among taxpayers (Agencies) (especially export companies) when they will apply for their rights (tax refunds). (Djuanda \& Lubis, 2011)

Related to that matter, several companies have complained about the difficulty of applying for VAT restitution at the Directorate General of Taxes. Whereas in Article 17B of the Law on General Provisions of Taxation (UU KUP), it is regulated that the Directorate General of Taxes must issue an Overpaid Tax Assessment Letter (SPKLB) no later than 12 months since Restitution application received in full. If the Directorate General of Taxes does not decide within that period, the application is considered granted, and the SKPLB is issued no later than 1 (one) month after the end of the period. Then, in paragraph (3), it is also regulated that if the Directorate General of Taxes is late in issuing SKPLB, the taxpayer will be given an interest rate of $2 \%$ per month, calculated from the end of the period. So, the KUP Law has provided legal certainty for taxpayers (corporates) (business actors) to apply for restitution. However, in practice, there are many factors hamper the process of paying restitution, such as bureaucracy, the interpretation of several articles in the Taxation Law, which can be vary, especially those concerning requests for completeness of documents or company data, and so on.

VAT restitution has a legal basis for Law no. 28 of 2007 and strengthened by Minister of Finance Regulation (PMK) 192/PMK.03/2007 and later changed to PMK Number 74/PMK.03/2012 and then it was changed again to PMK Number 198/PMK.03/2013, and the latest PMK Number 39/PMK.03/2018. The provision in the form of law is the government effort to inform the requirements of taxpayers/PKP in applying for VAT restitution. Meanwhile, the PMK which has been revised up to three times is a procedure for the implementation of the preliminary implementation of tax overpayments or acceleration of tax refunds/VAT restitution. Preliminary restitution or in this case the acceleration of VAT refunds is needed so that the PKP gets legal certainty that the excess VAT that has been deposited into the state can be submitted for restitution more quickly. (Sukardji, 2019)

Based on previous research, the author tries to explain how the process of the occurrence of Tax Overpayment Restitution. Restitution is an overpayment of Value-Added Tax that occurs because the amount of Input Tax paid is greater than the amount of Output Tax collected in a Tax Period. Productivity Restitution of decisions that stipulate the existence of tax overpayments, decisions in tax payments are tax assessments overpaid (SKPLB) which after being issued after going through an inspection process, examination of mass notification letters is required to be carried out to provide legal certainty on the status of tax payments from taxable employers. The Directorate General of Taxes will issue a Decision Letter on Preliminary Return of Excess Tax, namely a decision letter that determines the amount of the Preliminary Return on Excess Tax for Certain 
Taxpayers. Based on Article 7 paragraph (1) of the Regulation of the Minister of Finance Number 72/PMK.03/2010, the process of refunding the excess tax must be completed within 1 month after the complete application is received.

\section{METHOD}

This study uses a qualitative approach, which requires relevant and accurate data and information to support the research results. The kind of research used is descriptive qualitative, where the type of descriptive qualitative research is carried out by determining the data that will be used, collecting the data that has been determined, then grouping it, interpreting, and analyzing the data, and comparing it with theories, then a conclusion is taken and then gives a conclusion and it will be continued by suggestion. The descriptive method is a method in examining the status of a group of people, an object, condition, system of thought, or events in the present time. This type of research tried to explain certain social phenomena. Research can be divided into several types, based on differentiating criteria, including the final function and approach.

This research aims to determine how the Value-Added Tax restitution of PT. Rama Global, and how tax planning is used by PT. Rama Global in implementing tax restitution, by determining the data that will be used, and then collecting the data that has been determined, then grouping it, interpreting, and analyzing the data and comparing it with theories, then drawing a conclusion, and then providing suggestions. Based on the place of implementation, this research is field research, namely visiting the institution that is the object of research by asking for data and an explanation of what is being studied.

The definition of operational is a definition given to a variable by giving meaning or specifying an activity or justifying an operation needed to measure the variable. In this research, what is operationalized is the restitution of overpayment of taxes on exports by PT. Rama Global; obstacles in doing Restitution of tax overpayments on exports at PT. Rama Global; and efforts to overcome obstacles in refunding tax overpayments on exports to PT Rama Global in 2019.

Data collection techniques used in this research are Interview, Observation, Documentation Study and Triangulation. The author conducted unstructured interviews with people (employees) from the company. This interview was conducted by open interview. Observations that was made by the author aim to support the distribution of questionnaires. In this research, the informants interviewed were Finance Managers at PT. Rama Global, Tax Staff of PT. Rama Global, Tax Service Office Staff, and Academics.

Through observation techniques, the author will observe VAT Restitution and Tax Planning adjusts by selecting relevant informants. The author also collects data from various printed media that discusses the tax restitution of PT. Rama Global. This study uses three kinds of triangulations, firstly, triangulation of data sources in the form of information from places, events, and documents as well as archives containing notes related to the data in question. Second, triangulation techniques or data collection methods are derived from interviews, observations, and documents. Third, triangulation of data collection time is when triangulation or data collection methods are carried out. The validity of the data in the study was tested using triangulation techniques, namely triangulation of sources, data collection, and time.

The data analysis technique used in this study follows the data analysis technique. Data analysis consists of three stages, namely data reduction and data presentation, and conclusion. Data 
obtained from the results of research data collection in the form of interviews, observations, and documentation in the field objectively, then reduced by summarizing, choosing the main things, focusing on important things, looking for themes and patterns. Data reduction refers to the selection process, focusing on simplification, abstracting, and "rough" data information that occurs in written field notes. Data reduction is a form of analysis that sharpens, classifies, directs, discards unnecessary data, and organizes data in such a way that conclusions can be drawn and verified. Furthermore, the reduced data is presented in the form of sentences, pictures/schemas, networks, and tables as narratives. Finally, conclusions are drawn and verification is carried out. What is meant by data verification is an attempt to find, test, re-check or understand the meaning, regularities, patterns, explanations, plots, cause, and effect, or prepositions. While conclusions can be in the form of a description or description of an object that was previously dim or dark so that after being examined it becomes clear, it can be a causal or interactive relationship, hypothesis, or theory.

\section{RESULT AND DISCUSSION}

As an objective tax, VAT is charged on the delivery of goods and services. As indirect taxes, these two types of taxes ultimately become the burden of the final consumer who consumes goods and services. Theoretically, the imposition of indirect taxes can be delegated the tax burden to other parties, in this case, consumers or buyers. Meanwhile, the entrepreneur is a person or entity appointed by law to carry out tax obligations. Therefore, in the VAT provisions, those who become taxable entrepreneurs are entrepreneurs (sellers) as VAT subjects. PT. Rama Global in the VAT law is included in the subject of VAT in the sense of PKP.

Before running its business, PT. Rama Global has established itself as a PKP. This was clarified by the Tax staff of PT. Rama Global who stated that PT. Rama Global confirmed itself as a PKP in 2018. This was done to follow the tax rules and obligations that is applied in Indonesia. In addition, to avoid sanctions and ask for the rights from the Director-General of Taxes on obligations that will be or have been carried out by PT. Rama Global that is in s field of Export Company that exports all kinds of products.

In the VAT Law, the Value-Added rate is $0 \%$, so that PT Rama Global often experiences tax overpayments when reporting SPT. This is because the input tax is greater than the output tax. In this case PT. Rama Global chose to refund its tax overpayment. Restitution can be done by checking and can also be done by researching based on the tax laws and regulations. PT Rama Global carries out its restitution by choosing preliminary restitution.

The procedure for submitting a preliminary tax restitution is by submitting restitution in the preliminary restitution column on the VAT SPT. Reporting the SPT to the DGT Web or KPP registered and can be done online, then the KPP will research/check the reporting of tax invoices on each transaction opponent, and then issue a letter Tax Overpayment Decision (SKPLB). The tax overpayment that is refunded will be processed by the Director-General of Taxes for a minimum of 1 month for preliminary restitution and a maximum of 1 year for audits until the issuance of a Tax Assessment Letter.

Obstacles faced in conducting Preliminary Restitution with certain conditions at PT. Rama Global includes the differences in input tax corrections on the acquisition of domestic taxable goods or services, late reports from vendors in collaboration with PT. Rama Global so that there is a difference between the nominal stated on the SPPKP and the SPT which causes the Restitution 
cannot be liquidated and there is a fictitious tax invoice. From the statement above, it can be seen that PT Rama Global which performs preliminary restitution often cannot disburse tax refunds due to differences in data between the tax authorities and taxpayers. Efforts made by PT Rama Global to overcome the obstacles that occur are by reconfirming the VAT tax reporting included, whether it has been reported or not, then asking the BPE and Appendix A2 to be evidence and resubmitting it. From the above statement, we can know that PT. Rama Global deal with the problems that exist in the company is by confirming to the vendor or transaction partner, and aski for Electronic Receipt Evidence(BPE) along with attachment A2 and then visit the KPP to check the correctness of attachment A2 provided by the counterparty. From the research results obtained, it is known that PT. Rama Global is a taxable entrepreneur who must fulfill his obligations, namely, he is obliged to report his business to be confirmed as a PKP; obliged to collect VAT and Sales Tax on Luxury Goods or PPnBM payable; must deposit The VAT accrued in case the output tax is greater than the input tax can be credited. Besides that, PKP is also required to deposit PPnBM payable; obliged to report taxes in the SPT (Tax Return) Period of VAT, and must issue a tax invoice for each submission of BKP/JKP.

The rights of taxable entrepreneurs such as crediting taxes, making tax compensation or tax restitution, objections and appeals. As a PKP, PT. Rama Global Often experiences tax overpayments, this happens because PT Rama Global is a company engaged in the export sector where according to the VAT law the tax rate for exports is $0 \%$, so that it becomes the main cause that input tax is greater than output tax. This tax overpayment is always experienced every time, but the tax overpayment does not reach 1 (one) billion, so PT. Rama Global chooses to restitute taxes with certain requirements restitution criteria by the provisions of Article 17D of the KUP Law. Based on PMK 39/PMK.03/2018 concerning Procedures for Preliminary Refund of Excess Tax Payments, it is stated that the tax restitution is subject to certain conditions. PT. Rama Global is a Taxable Entrepreneur who submits a Periodic Value-Added Tax Return with an overpayment of less than 1 billion so that PT. Rama Global Performs VAT restitution with certain conditions. To obtain a preliminary return. In making restitution, it takes 1 (one) to 3 (three) months for the issuance of the Decision Letter for Payment of Excess Tax (SKPKP). After the issuance of the SKPKP, the director-general of taxes will send an account request letter and PT. Rama Global sends an account notification letter to the registered KPP and waits for 1 (one) month for payment of restitution. The following is a tax refund mechanism.

Figure 1. Tax Refund Mechanism with Certain Requirements Procedure

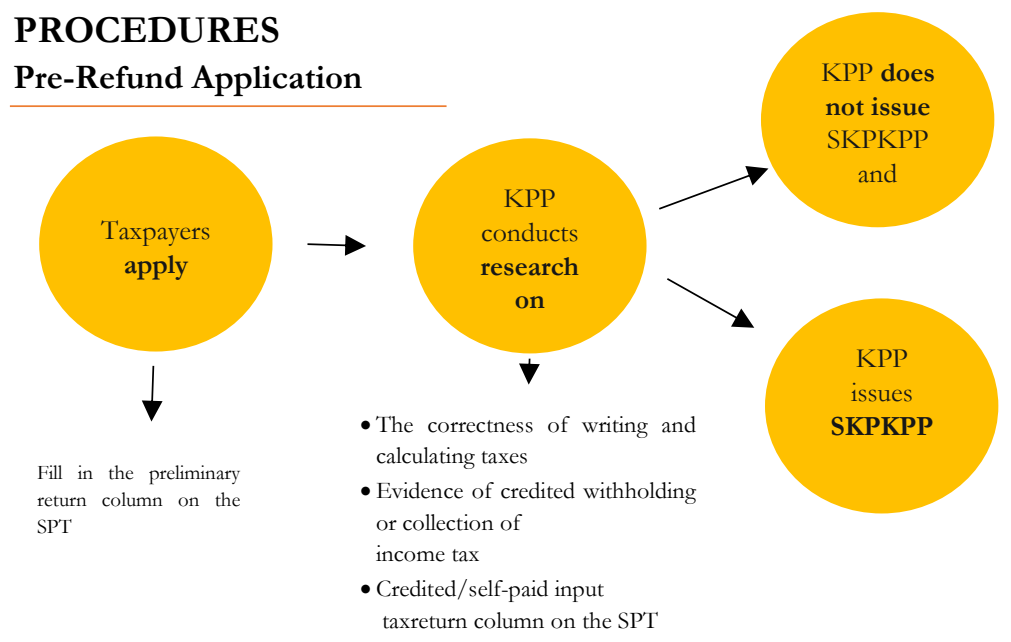


In making restitution, PT. Rama Global also needs to obey the applicable laws and regulations, starting from depositing taxes and reporting taxes that must be based on the provisions so that the restitution that we apply for can be fully refunded.

From the results of the research obtained by the researcher, it was found that the obstacles that occurred in carrying out preliminary restitution with certain conditions:

There is a large number of data differences between the tax authorities and PT Rama Global. The difference of the data occurred due to several multiple counterparties of PT. Rama Global who do not report their tax invoices or reports taxes in different months, resulting in delays in the restitution process.

From the interview research studied, the researcher also found that there was a risk PT. Rama Global. This risk arises due to the frequent occurrence of tax restitution at PT Rama Global so that there is a greater opportunity for the Director-General of Taxes (DGT) to make fiscal corrections from the tax audit process. The monitoring mechanism for Value-Added Tax (PPN) is the reporting of Periodic Tax Return (SPT) from certain Taxpayers (WP) reflecting transactions with counterparties. This allows the DGT to trace transactions between parties, to ensure that all taxes owed have been deposited into the State Treasury. In solving the problems faced by the company for restitution that can't be disbursed, PT. Rama Global confirms the transaction counterparty by sending attachments of related documents and notifying confirmation to the counterparty via e-mail by Requesting Electronic Receipt Proof (BPE) along with attachment A2; make an application letter to confirm the non-conformity; confirm by telephone about data discrepancies; visit the counterparty company to ask for further confirmation. In handling fictitious tax invoices, we can scan barcodes on tax invoices by using the Barcode scan e-invoice application or use the available tax invoice scan tools.

Efforts made during a tax audit are that PT Rama Global must be ready to face this audit by preparing complete documents such as Tax Invoices relating to VAT overpayments for which a refund restitution is requested, including supporting documents, namely evidence of receipt/payment of money for the purchase/sale of goods, evidence of delivery/receipt of goods. Furthermore, for BKP export attachments, it is necessary for PEB which has been given export approval by the authorized DJBC official, Ocean B/L or Master B/L or Airway Bill, Photocopy of export draft, or other evidence of receipt of money from the bank that has been legalized by the bank concerned, Certification from certain agencies such as the Ministry of Industry and or the Ministry of Trade.

\section{CONCLUSION}

Restitution of export Value-Added Tax (VAT) at PT. Rama Global occurs because the input tax is greater than the output tax, this is because the VAT rate for exports is $0 \%$. So that PT. Rama Global is experiencing tax overpayment. Excess tax payments that occur at PT. Rama Global is restituted by PT. Rama Global with Restitution Method with certain requirements under 1 billion. The obstacle that occurs during restitution is the difference in data between the tax authorities and the taxpayer, causing a tax correction on Value Added Tax (VAT) refunds, which is because the transaction partner has not reported the tax or has reported it in a different month. Efforts made by PT. Rama Global is confirming the value-added tax reporting data listed on the tax invoice to the relevant transaction partner.

Researchers suggest to do storing supporting documents as evidence for every transaction, especially those closely related to the request for restitution properly in a special room for 
approximately 5 (five) years or as long as it has not been checked by the Fiskus; Provide opportunities for tax staff to attend both formal and informal education in order to improve the competence and professionalism of human resources in the tax sector; Selection and placement of competent Human Resources (HR) in the field of taxation; There is special attention and direct support from top management and other related departments so that the process of applying for restitution does not experience delays or corrections in the examination; Make good use of the tax facilities provided by the Directorate General of Taxes that can help stabilize the company's cash flow, such as applying for the use of the "uncollected VAT" facility in its export activities or trying to become a Compliant Taxpayer.

\section{REFERENCE}

Amir, H., Asafu-Adjaye, J., \& Ducpham, T. (2013). The impact of the Indonesian income tax reform: A CGE analysis. Economic Modelling, 31, 492-501. https://doi.org/10.1016/j.econmod.2012.12.018

Ariawan, G. T. P., Handayani, S. R., \& Karjo, S. (2016). Analisis Time Value Of Money Atas Proses Penyelesaian Restitusi Pajak Pertambahan Nilai (Studi Kasus Terhadap Wajib Pajak Badan PT XY). Jurnal Perpajakan JEJAK, https://media.neliti.com/media/publications/193851-ID-analisis-time-value-of-moneyatas-proses.pdf

Asriati, \& Sasmito, C. (2016). Strategi Peningkatan Penerimaan Pajak Kendaraan Bermotor ( Pkb ) Dalam Meningkatkan Pendapatan. Manajemen, 12(2), 112-127. https://doi.org/https://doi.org/10.26618/jeb.v12i2.1886

Djuanda, G., \& Lubis, I. (2011). Pelaporan Pajak Pertambahan Nilai (II). Gramedia Pustaka Utama. https:/ / library.ui.ac.id/detail?id=20151629

Federici, D., Parisi, V., \& Ferrante, F. (2020). Heterogeneous firms, corporate taxes and export behavior: A firm-level investigation for Italy. Economic Modelling, 88, 98-112. https://doi.org/10.1016/j.econmod.2019.09.012

Hajawiyah, A., Suryarini, T., Kiswanto, \& Tarmudji, T. (2021). Analysis of a tax amnesty's effectiveness in Indonesia. Journal of International Accounting, Auditing and Taxation, 44, 100415. https://doi.org/10.1016/j.intaccaudtax.2021.100415

Harjo, D. (2019). Perpajakan Indonesia Sebagai Materi Perkuliahan di Perguruan Tinggi (D. Harjo (ed.); I). Mitra Wacana Media. https://www.mitrawacanamedia.com/perpajakan-indonesiasebagai-materi-perkuliahan-di-perguruan-tinggi-dwikora-edisi-2

Jusmani, \& Qurniawan, B. (2016). Pengaruh Restitusi Pajak Pertambahan Nilai Terhadap Penerimaan Pajak Pertambahan Nilai Pada Kantor Pelayanan Pajak Pratama Palembang Ilir Barat. Jurnal Media Wahana Ekonomika, 13(3), 130-142. https://doi.org/http://dx.doi.org/10.31851/jmwe.v13i3.2717

Mardiasmo. (2016). Perpajakan (Mardiasmo (ed.); III). Andi. http:/ /www.library.usd.ac.id/web/index.php?pilih $=$ search\&p $=1 \& q=0000133697 \& g o=$ Det ail

Octavia, S., Mayowan, Y., \& Karjo, S. (2015). Analisis Proses Restitusi Pajak pertambahan Nilai (PPN) di Indonesia. Jurnal Perpajakan JEJAK, 7(1), 1-9. https://media.neliti.com/media/publications/193533-ID-analisis-proses-restitusi-pajakpertamba.pdf 
Oktaria, R. (2011). Input Value Added Tax Refund Policy for Taxable Enterprise Experiencing Production Failures. Jurnal Ilmu Administrasi Dan Organisasi BISNIS \& BIROKRASI, 18(1), 43-52. http://journal.ui.ac.id/index.php/jbb/article/view/973

Rahayu, S. K. (2010). Perpajakan Indonesia : Konsep dan Aspek Formal (S. K. Rahayu (ed.); I). Graha Ilmu. http://inlislite.uin-suska.ac.id/opac/detail-opac?id=19839

Rahmadani, S. E., \& Munawaroh. (2017). Antisipasi Restitusi Pajak Pertambahan Nilai Atas Kegiatan Ekspor Dan Impor Pada PT YKK Zipco Indonesia. Jurnal Akuntansi Dan Bisnis Krisnadwipayana, $\quad 4(2), \quad 34-50 . \quad$ https://ojs.ekonomiunkris.ac.id/index.php/JABK/article/view/120

Rahwani, N. R., Sadewa, M. M., Qalbiah, N., Mukhlisah, N., Artha W, P., \& Nikmah, N. (2019). XBRL based Corporate Tax Filing in Indonesia. Procedia Computer Science, 161, 133-141. https://doi.org/10.1016/j.procs.2019.11.108

Rehm, J., Neufeld, M., Room, R., Sornpaisarn, B., Štelemèkas, M., Swahn, M. H., \& Lachenmeier, D. W. (2021). The impact of alcohol taxation changes on unrecorded alcohol consumption: A review and recommendations. International Journal of Drug Policy, 103420. https://doi.org/10.1016/j.drugpo.2021.103420

Rokhmawati, A. (2021). The nexus among green investment, foreign ownership, export, greenhouse gas emissions, and competitiveness. Energy Strategy Reviews, 37, 100679. https://doi.org/10.1016/j.esr.2021.100679

Samudra, A. (2008). Restitusi PPN atas Kegiatan Ekspor Dalam Konteks Perencanaan Pajak (Studi Kasus PT. YI). Jurnal Administrasi Bisnis, 3(1), 59-61. https://library.ui.ac.id/detail?id=125122

Solleder, J.-M. (2020). Market power and export taxes. European Economic Review, 125, 103425. https://doi.org/10.1016/j.euroecorev.2020.103425

Sukardji, U. (2019). Pokok-pokok PPN (Pajak Pertambaban Nilai) Indonesia (U. Sukardji (ed.); 12th ed.). RajaGrafindo Persada. https://www.rajagrafindo.co.id/produk/pokok-pokok-ppn/

Tran, C., \& Wende, S. (2021). On the marginal excess burden of taxation in an overlapping $\begin{array}{lllll}\text { generations model. Journal of Macroeconomics, } & \text { 70, } & 103377 .\end{array}$ https://doi.org/10.1016/j.jmacro.2021.103377

Zhang, Y., Abbas, M., \& Iqbal, W. (2021). Analyzing sentiments and attitudes toward carbon taxation in Europe, USA, South Africa, Canada and Australia. Sustainable Production and Consumption, 28, 241-253. https://doi.org/10.1016/j.spc.2021.04.010 